2. To: (Receiving Organization)

SNF Projects

5. Proj-/Prog./Dept./Div.:

Spent Nuclear Fuel/

Cold Vacuum Drying Facility/

Project $\mathrm{H}-441$

3. Fron: (Originating organization)

SNF Cold Vacuum Drying

Project

6. Design Authority/ Design Agent/Cog.

C. C. Pitkoff $\quad 3 / 6.5655$
4. Related EDT No.:

$\mathrm{n} / \mathrm{a}$

7. Purchase Order No.:

$$
n / a
$$

8. Originator Remarks: For Release

11. Receiver Remarks: 11A. Design Baseline Document? [] Yes [X] No

9. Equip./Component No.:

$\mathrm{n} / \mathrm{a}$

10. System/Bldg./Facility:

$\mathrm{n} / \mathrm{a}$

12. Major Assm. Dwg. Ho.:

$\mathrm{n} / \mathrm{a}$

13. Permit/Permit Application No.: $n / a$

14. Required Response Date: $9 / 18 / 98$

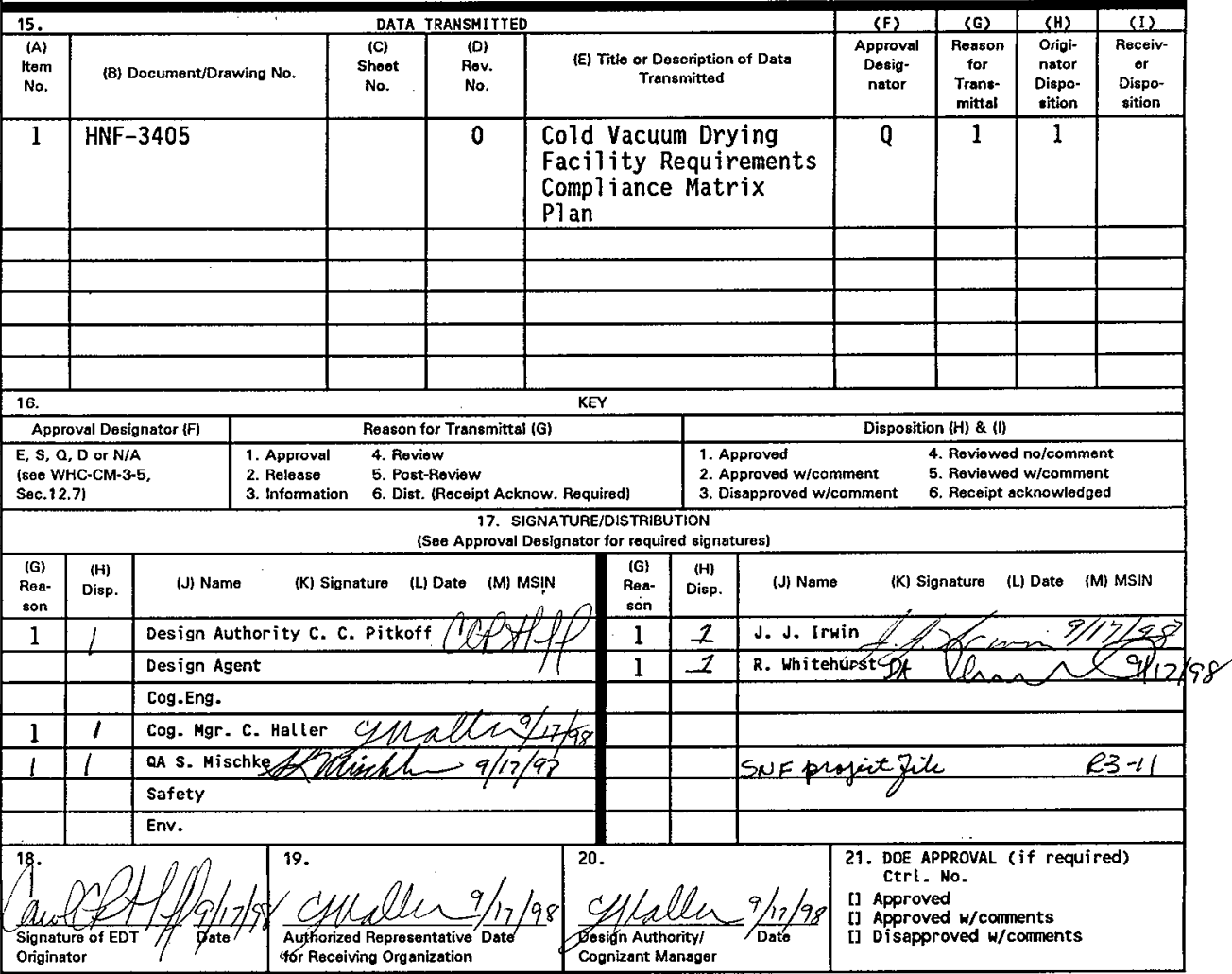




\title{
COLD VACUUM DRYING FACILITY REQUIREMENTS COMPLIANCE MATRIX PLAN
}

\author{
C. C. Pitkoff \\ DE\&S Hanford, Inc., Richland, WA 99352 \\ U.S. Department of Energy Contract DE-AC06-96RL13200
Org Code:
B\&R Code: 39Ew 70400 Total Pages: 5 \\ EDT/ECN: $625686 \quad$ UC: 2000
}

Key Words: SNF, Cold Vacuum Drying

Abstract: The Cold Vacuum Drying Facility Project is preparing a document that verifies the design meets the requirements. This document provides the plan to complete this scope of work.

TRADEMARK DISCLAIMER. Reference herein to any specific comnercial product, process, or service by trade name, trademark, manufacturer, or otherwise, does not necessarily constitute or imply its endorsement, recomendation, or favoring by the United states Government or any agency thereof or its contractors or subcont ractors.

Printed in the United States of America. To obtain copies of this document, contact: Document Control Services, P.0. Box 950, Mailstop H6-08, Richland WA 99352, Phone (509) 372-2420; Fax (509) $376-4989$.

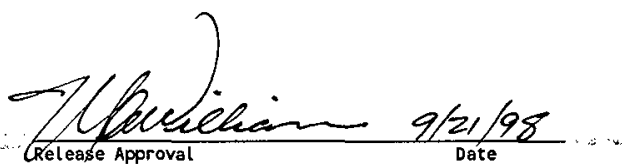

SEP 219998 2.

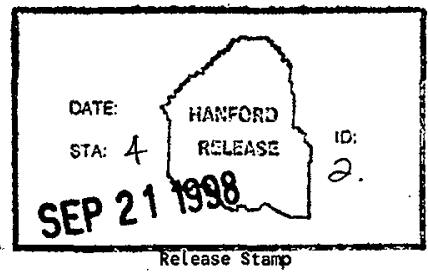




\author{
HNF-3405 Rev, 0 \\ Cold Vacuum Drying Facility \\ Requirements Compliance Matrix Plan
}

\title{
BACKGROUND
}

The Cold Vacuum Drying (CVD) Project is preparing a compliance matrix to verify the design meets all the requirements imposed by the CVDF Design Requirements Document. The matrix will be an issued document that records compliance with the design criteria. The document will be comprised of three sections, DRD compliance matrix, 6430.1A specific compliance matrix, and NRC equivalence specific compliance matrix.

\section{SCOPE}

The scope of this document is to outline the process that will be used to prepare the compliance matrix document, track open or non compliance issues and the process for closing the open items. All open items must be closed prior to issuing the Final Safety Analysis for the CVDF.

\section{RESPONSIBILITIES}

The CVDF Project has three Design Authorities (DA) who are collectively responsible for the overall technical adequacy of the project. The Title III activities are covered by two A/E's, one for facility construction and one for process equipment. The Project team is also involved in providing designs for special tools, project furnished equipment.

DA responsibility

- $\quad$ Provide a requirements to the $\mathrm{A} / \mathrm{E}$

- Review and approve design documentation prior to procurement or construction

- Verify design meets requirements

$\mathrm{A} / \mathrm{E}$ and Project design team responsibility

- Provide a design that meets the requirements

- Provide basis for design (this includes calculations)

\section{COMPLIANCE MATRIX}

A compliance matrix will be prepared to verify the various $\mathrm{CVDF}$ designs meet all requirements imposed by the project Design Requirements Document (DRD) HNF-SD-SNF-DRD-002, Spent Nuclear Fuel Project Cold Vacuum Drying Facility Design Requirements Document. The matrix will be presented in three sections. The first section will show the compliance with the DRD. The second section will be a DOE Order 6430.1A specific compliance matrix. The third section will be a NRC equivalency specific matrix applying design basis documents, HNF-SD-SNF-DB-003, 
HNF-3405 Rev. 0

Cold Vacuum Drying Facility

Requirements Compliance Matrix Plan

Spent Nuclear Fuel Project Path Forward Additional NRC Requirements and HNF-SD-SNF-DB101, Cold Vacuum Drying Systems Natural Phenomenons Hazards.

The Compliance Matrix will be an issued document per HNF-PRO-244, Engineering Data

Transmittal Requirements. Modifications to the document will follow HNF-PRO-440

Engineering Document Change Control Requirements.

\section{FORMAT}

The Compliance Matrix will be prepared in a table format. The table will have as a minimum the following headings:

- Section (were requirement is located)

- Requirement

- Status (compliant, C, non-compliant, NC, to be determined, TBD)

- Evaluation/comments

Each page will have a heading and page number. Supporting documentation that helps show compliance may be provided, as appropriate, in the evaluation/ comments section.

\section{NON-COMPLIANCE AND TO BE DETERMINED RESOLUTION PROCESS}

Requirements in the matrix that contain TBDs or NC will be closed by modification to the matrix using the ECN process. A TBD will be closed when the information has been provided by the design agent $(A / E)$ or the project. The $D A$ will be responsible for preparing the modification and issuing the change. All TBDs will be tracked on a punch list. The punch list will become a project level schedule activity.

Requirements that are not captured in the design will be status as non-compliant(NC). Closure of a NC item will require one of the following to close

- Justification from the A/E as to what code or standard was used, why it was used and how it compares with the requirement.

$$
\text { and }
$$

- Justification from the DA that the requirement has been met via the above information.

or

- Change to the design to meet the requirement

or

- Reference and describe a waiver from the requirement. 


\author{
HNF-3405 Rev. 0 \\ Cold Vacuum Drying Facility \\ Requirements Compliance Matrix Plan
}

All NCs will be tracked on a punch list that will be maintained by the DAs. The punch list will become an activity on the project level schedule. The following page is a copy of a punch that will be used to track open items. 
HNF-3405 Rev. 0

Cold Vacuum Drying Facility

Requirements Compliance Matrix Plan

Punch list

CVDF Project Compliance Matrix

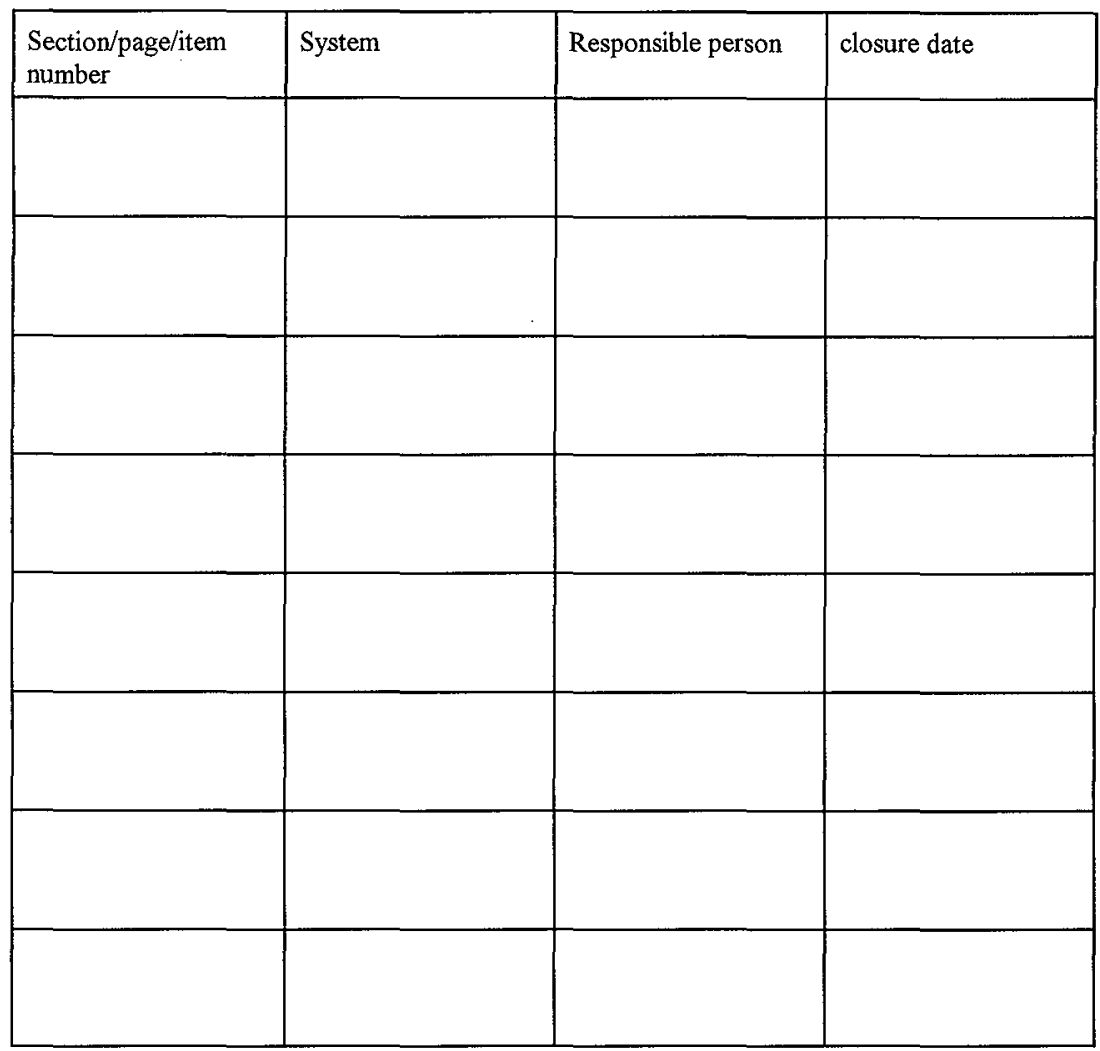

